\title{
The Challenges of PRIOR USE TO NeW ZEALAND REgistered TRADE MARK LAW
}

\author{
Rob Batty*
}

Under the Trade Marks Act 2002, the registrant of a trade mark is provided with the exclusive rights to use its trade mark. Priority to such exclusive rights is awarded to the person who files a trade mark application first. A searchable Register of trade marks enables traders and the public to see which trade marks have already been registered and by whom. This seemingly certain system is complicated by the continuing relevance of unregistered trade marks under New Zealand law. The first user of a trade mark in the marketplace is considered the true "owner" or "proprietor" of a trade mark. A prior user of an unregistered mark is able to prevent registration of a trade mark, or cancel an existing trade mark registration, even when the application was filed in ignorance of any prior use and where there is no prospect of consumer confusion. This article explores the unsatisfactory nature and consequences of this law of "proprietorship" and questions its continuing relevance.

\section{INTRODUCTION}

The Trade Marks Act 2002 (2002 Act) governs New Zealand's registration system for trade marks. Registration is typically touted as a way of protecting a trader's investment in a trade mark. ${ }^{1}$ The 2002 Act provides the owner of a registered trade mark with the exclusive rights to use the mark, ${ }^{2}$ and a statutory right to take action to restrain infringement of its exclusive rights by others. ${ }^{3}$ The security provided by these registration rights can provide confidence to traders prior to committing expenditure to market products under that mark. Once trademarked products are in the

* Senior Lecturer, University of Auckland Business School. My thanks to Earl Gray, Paul Sumpter, Richard Watts, Emma Willis, Sarah Bewick, Pam Kam and the anonymous reviewer for their helpful comments on earlier drafts.

1 See for example Intellectual Property Office of New Zealand "Why Register a Trade Mark?" (20 March 2009) <www.iponz.govt.nz>.

2 Trade Marks Act 2002, s 10.

3 Trade Marks Act 2002, s 89. 
marketplace, the exclusive rights provided by a registration can prevent third parties freeriding on goodwill associated with a trade mark. The 2002 Act also provides for a searchable register of trade marks. The Register is said to play an important information role. ${ }^{4}$ The public, and other traders, can ascertain what marks have been registered and by whom.

The operation of the registration system, and the information role played by the Register, is complicated by the presence of unregistered trade marks in the marketplace. Unregistered trade marks can attract independent protection through the common law tort of passing off and the Fair Trading Act 1986. The dual forms of protection that coexist for trade marks create difficulties when there are competing claims to rights in a trade mark. One problem that emerges is when a trader seeks to register or enforce rights in a registered trade mark that has been used at an earlier point of time by someone else. The earlier, prior user of the mark may claim the person applying or registered as the owner of the trade mark is not the valid "owner" of the trade mark. This article is about such prior use disputes.

Under the 2002 Act, priority to the benefits of registration is given to the person who files an application first. ${ }^{5}$ However, under New Zealand law the person who uses a trade mark first in time in the marketplace holds a trump card. A prior user of the same unregistered trade mark can oppose a trade mark application or invalidate an existing registration, based on their prior use. Such a prior use challenge will be successful even when the trade mark application was filed in good faith. This law of proprietorship is a by-product of the New Zealand trade mark system's common law heritage, whereby "proprietorship" of a trade mark is governed by first use. ${ }^{6}$

This article argues that the law of proprietorship has developed in a way that is unsatisfactory and potentially detrimental to the effective functioning of the modern registered trade mark system. In particular, the current law potentially creates uncertainty over the validity of existing registrations and doubt for traders looking to clear new marks for use. It is not disputed that where use of a mark would be likely to cause marketplace confusion because of an existing unregistered right, registration should be refused. Rather, it is contended that there may be merit in reforming the law to remove a ground of challenge based on the mere prior use of the same mark by another. Any legislative change, though, would need to be carefully considered in light of how registered and unregistered marks coexist generally under New Zealand law. If prior use challenges are maintained, it is suggested that the law would be improved if the judiciary and the Intellectual

4 For discussion of the information role of trade mark registers see Robert Burrell "Trade Mark Bureaucracies" in Graeme Dinwoodie and Mark Janis (eds) Trademark Law and Theory: A Handbook of Contemporary Research (Edward Elgar, Cheltenham (United Kingdom), 2008) 95-131.

5 Trade Marks Act 2002, s 34.

6 New Zealand's system can be compared to civil law based systems such as Japan and France which adopt a first to file system. Under a first to file system the exclusive rights to a trade mark are given to the first person to file an application, irrespective of who used the mark first. 
Property Office (IPONZ) adopted a more rigorous approach to assessing whether there has been prior use of an identical or substantially identical trade mark.

In Part II of this article, I will explain how ownership disputes arise by sketching the messy forms of dual protection that exist for trade marks under New Zealand law. In Part III, I will explain that, although there is no explicit statutory basis for challenges based on prior use, prior user claimants have been permitted to shoe-horn their claims into multiple sections of the 2002 Act. In evaluating prior use claims under these sections, IPONZ and the courts have applied a common law test of proprietorship based on prior use. In Part IV, I examine this judge-made test of "proprietorship". In Part V, I demonstrate the unsatisfactory elements of this proprietorship test based on prior use and suggest how it is doctrinally misaligned with contemporary trade mark law and denigrates the efficacy of the registered trade mark system. Part VI outlines how, if the law of proprietorship is to be maintained, it could be improved by raising the threshold of use of a mark that must be demonstrated before there can be a challenge to an extant application or registration. Part VII concludes.

\section{THE CONTEXT FOR OWNERSHIP DISPUTES}

\section{A Historical Development of a Messy Form of Dual Protection}

Under the 2002 Act there is no requirement that a trader seeking registration must have put a trade mark to prior use before filing an application. A trader need only have a genuine intention to use the trade mark applied for. ${ }^{7}$ Further, as filing an application is taken to be prima facie evidence of such an intention, ${ }^{8}$ it is rare for there to be any inquiry into the validity of a trader's intention. The trade mark must also be capable of distinguishing goods, ${ }^{9}$ and it must be sufficiently inherently (or factually) distinctive to be able to communicate the source of goods. ${ }^{10}$ If these qualifying conditions are satisfied a trader may become the owner of a registered trade mark independent of actual use in the marketplace.

By contrast, at common law, ownership of unregistered trade marks depends on use. Historically, the person who first used a mark in conjunction with goods was considered the

7 The necessity for an intention is not spelt out as an explicit requirement in the 2002 Act. Compare Trade Marks Act 1994 (UK), s 32(3). However, the Trade Mark Regulations 2003, r 44(j) stipulates that a trade mark will not be accepted until the applicant provides a statement that the trade mark is being used or is proposed to be used.

8 Effem Foods Ltd v Cadbury Ltd HC Wellington CIV 2005-485-1487, 21 March 2007 at [34].

9 Trade Marks Act 2002, s 18(1)(a) and s 5.

10 Trade Marks Act 2002, s 18(1)(b). See AA Insurance Ltd v AMI Insurance Ltd [2012] 1 NZLR 837 (HC) at [1]: "A trade mark must communicate the origin of a product in trade. If it does not, it will not be entitled to the monopoly advantages that trade mark registration provides." 
owner. ${ }^{11}$ As with a registered trade mark, a common law mark had to be distinctive. But if that condition was met, courts declared that a trader acquired ownership over a mark merely by using the mark, irrespective of the length of such use. ${ }^{12}$ In the absence of use, the person with the best claim to ownership was considered to be the inventor or designer of the mark. ${ }^{13}$

To understand the nature of the disjoint between common law and the 2002 Act in terms of how ownership is determined, it is useful to provide some historical context. Prior to the first trade mark registration legislation, ${ }^{14}$ the common law provided an action to prevent the misuse of a mark premised on the prevention of fraud. ${ }^{15}$ One of the disadvantages of relying on the common law to enforce rights in a trade mark was the evidentiary difficulties in establishing first use and distinctiveness. The registration system established by the Trade Marks Registration Act 1875 provided a clear indication of title to a trade mark, and avoided the need for a trader to go to the cost and trouble of establishing that it was the owner of the mark. ${ }^{16}$ The 1875 Act also provided a further inducement for the registration of trade marks by providing that a trader could not take action for trade mark infringement until its trade mark was registered. ${ }^{17}$

The 1875 Act did not interfere with the notion that use was central to the acquisition of rights. Rather the 1875 Act adopted the fiction that registration was the same as public use. ${ }^{18}$ Subsequent legislation went further and allowed applications to register unused distinctive marks on the basis of

11 North Shore Toy Co Ltd v Charles L Stevenson Ltd [1973] 1 NZLR 562 (SC) at 567-568 referring to GE Trade Mark [1973] RPC 297 (HL) and Re Kenrick and Jefferson Ltd's Application (1909) 26 RPC 641.

12 Nicholson \& Sons Ltd's Application (1931) 48 RPC 227 (CA) at 253 cited in AL BASSAM Trade Mark [1995] RPC 511 (CA) at 522.

13 Re Hudson's Trade Mark (1886) 3 RPC 155 (CA) at 160 and 163 cited in AL BASSAM Trade Mark, above n 12 , at 522 .

14 New Zealand's first trade mark law was the Trade Marks Act 1866. However, from 1889, New Zealand trade mark law has followed the form of United Kingdom legislation. See the discussion in Villa Maria Wines Ltd v Montana Wines Ltd [1984] 2 NZLR 422 (CA) at 425-426.

15 See generally Lionel Bently "From Communication to Thing: Historical Aspects of the Conceptualisation of Trademarks as Property" in Graeme Dinwoodie and Mark Janis (eds) Trademark Law and Theory: A Handbook of Contemporary Research, above n 4, at 3-41.

16 Spalding v Gamage (1915) 32 RPC 273 (HL) at 284-285 per Lord Parker of Waddington:

Indeed, the necessity of proving this distinctiveness in each case as a step in the proof of false representation relied on was one of the evils sought to be remedied by the Trade Marks Act 1875 ...

17 Trade Marks Registration Act 1875, s 1. Although owners of trade marks in use before 13 August 1875 could still assert the right to sue for "infringement" if registration of their trade marks had been sought and refused under the Act. See British Telecommunications Plc v One in A Million Ltd [1999] 1 WLR 903 (CA) at 911 citing Orr Ewing $v$ Registrar of Trade Marks (1879) 4 App Cas 479 at 498.

18 Trade Marks Registration Act 1875, s 2; Re Hudson's Trade Mark, above n 13, at 163. 
intended use. Under the 1905 Act, and subsequent legislation, registration, not use, became the source and evidence of ownership of a trade mark. ${ }^{19}$ Yet, the advent of intent to use applications failed to alleviate conceptual difficulties in reconciling the common law of trade marks with a registration system. While legislation may have barred enforcement of common law marks, the registration system did not extinguish their existence and continued survival. ${ }^{20}$

Around the same time these legislative developments were occurring, judges crystallised the theoretical basis of their intervention in cases involving the misuse of unregistered trade marks. The legal basis took the form of the tort of passing off, which prohibits another person falsely representing its goods as the goods of somebody else. ${ }^{21}$ The courts conceptualised the proprietary interest protected in a passing off action as the business to which goodwill is attached, rather than the mark itself. ${ }^{22}$ By focusing attention on property in goodwill, rather than property in a mark, the question was not necessarily who was first to use a mark but whether a trader had a commercial reputation in an identifying mark. In general, the law adopted a "first-past-the-post" approach to the establishment of goodwill. ${ }^{23}$

Given that passing off focused attention on property in goodwill rather than property in a mark, it was possible for two persons to adopt identical or near identical marks, and for each to have a separate and distinct right to use the same mark. ${ }^{24}$ Each trader could take action against third parties using the same mark, but as between themselves the law provided an immunity. ${ }^{25}$ Some courts explained that in such a situation there is no misrepresentation - "each represents nothing but the truth, that a particular mark or name is associated with his goods or business". ${ }^{26}$

The registration system faced a related difficulty when multiple traders who had used trade marks concurrently in different locations sought registration. The legislation initially prohibited registration of identical marks. ${ }^{27}$ To address potential harsh results for long-term concurrent users,

19 British Telecommunications Plc v One in A Million Ltd, above n 17, at 911.

20 See North Shore Toy Co Ltd v Charles L Stevenson Ltd, above n 11, at 567.

21 Reddaway v Banham [1896] AC 199 (HL) at 204.

22 Spalding v Gamage, above n 16, at 284.

23 See Christopher Wadlow The Law of Passing Off (4th ed, Sweet and Maxwell, London, 2011) at [5-175] and [9-098].

24 Phillip Johnson "The Rise and Fall of Honest Concurrent Use" in Ilanah Simon Fhima (ed) Trade Mark Law and Sharing Names: Exploring Use of the Same Mark by Multiple Undertakings (Edward Elgar, Cheltenham (United Kingdom), 2009) 31 at 33.

25 The term "immunity" is from Wadlow, above n 23, at [9-096].

26 Habib Bank Ltd v Habib Bank AG Zurich [1981] 1 WLR 1265 (CA) at 1275. Compare the discussion of "honest concurrent use" in GE Trade Mark, above n 11, at 326.

27 See Trade Marks Registration Act 1875 (UK), s 6. 
the 1905 Act explicitly introduced a provision that permitted the registration of a mark where it had been honestly put to concurrent use with an existing registration or where other special circumstances were present. ${ }^{28}$ Yet, unlike under passing off, registered trade mark law did not provide immunity in cases of concurrent use of an unregistered mark. ${ }^{29}$

The end result of the historical development of the law regarding trade marks was the creation of a rather uneasy relationship between common law marks, registered trade marks and the tort of passing off. This problematic interface continues today. ${ }^{30}$ The 2002 Act provides that "no person may bring proceedings to prevent, or to recover damages for, the infringement of an unregistered trade mark" - meaning that trade mark infringement remains limited to registered marks. ${ }^{31}$ However, the 2002 Act does not affect the law relating to passing off or rights under the Fair Trading Act $1986 .{ }^{32}$ This means that, even if a trader has a registered trade mark, it does not have a defence to an action for passing off where all the elements of the tort are present. ${ }^{33}$

The interests of prior users of unregistered trade marks, though, are protected from infringement. The owner of an unregistered mark that has been used continuously prior to both the priority date of registered mark and first use of the registered mark has a defence to trade mark infringement. ${ }^{34}$ The 2002 Act also continues to contain honest concurrent use provisions that potentially allow the owner of an unregistered mark to register its mark alongside an existing registration. ${ }^{35}$

28 Trade Marks Act 1905 (UK), s 21. However, it should be noted that after the Trade Marks Registration Act 1875 was passed the Registrar of Trade Marks introduced a "three mark rule" which allowed up to three identical marks to be registered in cases of bona fide use. See generally Johnson, above n 24 .

29 A defence was only provided for antecedent continuous use: see Trade Marks Act 1905 (UK), s 41. A nonstatutory defence of acquiescence may be possible though: see Intellectual Property Development Corporation Pty v Primary Distributors New Zealand Ltd (2008) 8 NZBLC 102,274 (HC) at [58]-[65].

30 For further discussion on this messy interface from an Australian perspective see Robert Burrell and Michael Handler "The Intersection Between Registered and Unregistered Trade Marks" (2007) 35 FL Rev 375 .

31 Trade Marks Act 2002, s 99.

32 Trade Marks Act 2002, s 88.

33 See Arthur Martin (Sales) Ltd v Electra Mechanics (1975) Ltd (1986) 1 TCLR 365 at 370.

34 Trade Marks Act 2002, s 96.

35 Trade Marks Act 2002, s 26. However, such a provision does not appear to assist a person seeking to register a trade mark where it has made concurrent use but the owner of an unregistered mark with a prior reputation opposes the application to register under s 17(1)(a). See Fonterra Brands (Tip Top Investments) Ltd v Tip Top Restaurant Ltd HC Wellington CIV 2011-485-1011, 4 November 2011 at [60]. For a discussion of the issue from an Australian perspective see B Salter and H May Black "Prior Reputation 'Trumps' Honest Concurrent Use - Or Does It?" (2008) 74 IP Forum 41. 


\section{B How the Problem of Dual Protection Contributes to Ownership Disputes}

While it is not mandatory to register a trade mark, many traders do. ${ }^{36}$ Some traders carry out a search of the Register before applying to register or use a trade mark. Because of the system of dual protection, searching the Register does not capture unregistered marks. ${ }^{37}$ Some traders also try and ascertain the existence and scope of any unregistered rights by carrying out searches. The exercise of examining marks in use in the marketplace has become much easier with internet search engines and searchable public databases, such as telephone and business directories and online shopping websites. Nevertheless, searching and evaluating the nature of unregistered trade marks remains a rather imprecise and inexact exercise.

One of the difficulties in establishing the nature and scope of rights in unregistered trade marks is the principle of territoriality. This principle of "territoriality" is central to trade mark law, and is multi-faceted. ${ }^{38}$ One aspect of the territoriality principle is that trade mark rights are territorial in scope. Registered trade mark rights extend nationwide, but no further. Under passing off, the territorial scope of a trader's goodwill defines the scope of protection. Goodwill may be restricted to a particular local area, such as parts of the South Island, ${ }^{39}$ or it might not extend into certain areas of the country. ${ }^{40}$

A second facet of territoriality is that trade mark rights must be acquired nationally. In determining whether a mark connotes the goods of a particular manufacturer, only use in New

36 See Basil Sharp and Owen Morgan Review of the New Zealand Intellectual Property System (Uniservices Ltd, Auckland, prepared for the Ministry of Economic Development, April 2010) at 45 and Table 11 reporting that registered trade marks are a commonly used form of intellectual property protection (based on a survey of IP advisors). See also Table 22 at 70 showing high use of trade marks as an IP instrument (based on an IP awareness survey of businesses).

37 For an interesting discussion of the problem of "false negatives" see Robert Burrell "Trade Mark Bureaucracies" in Dinwoodie and Janis, above n 4, 95 at 100-102.

38 Graeme Dinwoodie "Trademarks and Territory: Detaching Trademark Law from the Nation-State" (2004) 41 Hous LR 885 at $892-893$.

39 See for example New Zealand Farmers Co-operative Association of Canterbury Ltd v Farmers Trading Co Ltd (1979) 1 NZIPR 212 (SC) and 224 (plaintiff with a reputation in parts of the South Island and the defendant with a reputation in the North Island) cited in Andrew Brown and Anthony Grant The Law of Intellectual Property (Wellington, Butterworths, 1989) at [3.24].

40 Fresh Direct Ltd v Fresh Direct Wholesale Ltd HC Blenheim CIV-2003-406-20, 18 December 2003 (plaintiff's reputation did not extend to the Nelson-Marlborough area where the defendant operated) cited in I Finch (ed) James \& Wells Intellectual Property Law in New Zealand (2nd ed, Thomson Reuters, Wellington, 2012) at 773-774. Compare Muzz Buzz. Franchising Pty Ltd v JB Holdings (2010) Ltd [2013] NZHC 1599. 
Zealand is relevant. ${ }^{41}$ Under the registered trade mark system, if a trader wants to extend its registered rights outside of New Zealand it must file a separate trade mark application in each country of interest. ${ }^{42}$ In terms of passing off, the situation appears more fluid. Under New Zealand law it has been accepted that goodwill can cross national borders, provided that there is a business connection in the jurisdiction. ${ }^{43}$ Moreover, as between Australia and New Zealand, it has been recently held that a well-established reputation in Western Australia, combined with internet access to the business and sponsorship in a Trans-Tasman sporting competition, was sufficient to support a passing off action in New Zealand. ${ }^{44}$

An historical by-product of the territoriality of trade marks was that it was possible for more than one trader within a country to innocently market their goods with the same trade mark without the prospect of consumer confusion. Today, with the improvement in the reach of communications, not to mention the pervasiveness of the internet, this prospect is less likely. Nevertheless, there may be instances of geographically limited or small scale prior use that may escape detection and lead to innocent co-adoption of the same mark. ${ }^{45}$

A more common consequence of the territoriality of trade marks is that, even in an era of greater global interconnectedness, the same mark may exist in different countries but be registered to, or used by, different persons. The reported cases indicate that a local trader's adoption of the same mark as a mark used or registered overseas often involves a conscious attempt to cash in on the international reputation a trade mark enjoys. ${ }^{46}$ For example, in Pioneer Hi Bred Corn Co v Hy-Line Chicks Pty Limited a mark comprising "HY-LINE" superimposed on the image of a chicken had

41 See Impex Electrical Ltd v Weinbaum (1927) 44 RPC $405(\mathrm{Ch})$ at 410: "For the purpose of seeing whether the mark is distinctive it is to the market of this country alone that one has to have regard." See also Seven UP Co v OT Ltd [1947] HCA 59, (1947) 75 CLR 203.

42 Although the Paris Convention for the Protection of Industrial Property 828 UNTS 107 (20 March 1883, last revised at Stockholm 14 July 1967, last amended 28 September 1979) enables applicants to file applications in convention countries with a six month right of priority. In addition, the Protocol Relating to the Madrid Agreement Concerning the International Registration of Marks (27 June 1989, entered into force 1 December 1995) also enables a trader to apply to protect a trade mark in several countries by filing one "international" application with a national or regional trade mark office [The Protocol]. On 10 September 2012 New Zealand formally deposited with the World Intellectual Property Organisation (WIPO) the Instrument of Accession to the Madrid Protocol.

43 See Dominion Rent-A-Car Ltd v Budget Rent-A-Car Systems (1970) Ltd [1987] 2 NZLR 395 (CA) at 406. Compare Star Industrial Co Ltd v Yap Kwee Kor [1976] FSR 256 (PC) at 269.

44 Muzz Buzz. Franchising Pty Ltd v JB Holdings (2010) Ltd, above n 40. It was noted at [74] "In 2013, it can hardly be doubted that New Zealand and Australia may, for the purposes of enforcing intellectual property rights, be regarded as one market."

45 See for example P B Foods Ltd v Malanda Dairy Foods Ltd [1999] FCA 1602, (1999) 47 IPR 47 (one party using the mark in Queensland and the other party in Western Australia).

46 See for example Seven UP Co v OT Ltd, above n 41. 
been used in the United States since 1941 by an American company for poultry. The company had sold its product under the mark in 48 countries establishing an international reputation. However, because of import restrictions on poultry, no sales had occurred in New Zealand. In 1963, an Australian company applied to register the mark HY-LINE for poultry in New Zealand. Cooke J characterised the actions of the Australian company as "an obvious and fairly simple case of appropriation or copying of a foreign trader's mark". ${ }^{47}$

Another category of cases involving ownership disputes arises when relationships between parties break down and there is a dispute as to who is the owner of the mark. Typically, in the reported cases this occurs between overseas manufacturers and local distributors. When a manufacturer places its trade mark on goods, the trade mark will generally continue to indicate that the goods originate from the manufacturer despite passing through the hands of a distributor. ${ }^{48}$ However, in some circumstances the distributor may allege that it has disassociated itself from the original significance of the manufacturer's mark as an indicator of the manufacturer's goods and that the trade mark has become "exclusively indicative" of the local distributor's goods. ${ }^{49}$ The distributor may then argue that it has established ownership of the trade mark.

\section{When Does a Challenge to Ownership on the Grounds of Prior Use Have Work to Do?}

In cases of deliberate or coincidental adoption, or in disputes between overseas manufacturers and local distributors, the question is often a relative contest as to which party made use of the mark first. The context in which this article analyses such disputes is where a person seeks to challenge the validity of a trade mark application or registration. There are three main opportunities for a prior use challenge. First, "any person" has an opportunity to come forward within three months of acceptance of an application and question whether a trade mark should be registered by instigating opposition proceedings. ${ }^{50}$ Secondly, after a trade mark is registered, an "aggrieved person" can seek to have a trade mark invalidated and removed from the Register on the grounds that it should not have been registered. ${ }^{51}$ Thirdly, a defendant to an action for infringement of a trade mark may claim a trade mark registration is invalid as a defence.

47 Pioneer Hi-Bred Corn Company v Hy-Line Chicks Pty Limited [1975] 2 NZLR 422 (SC) at 426.

48 Estex Clothing Manufacturers Pty Ltd v Ellis \& Goldstein Ltd [1967] HCA 51, (1967) 116 CLR 254 at 272.

49 See Bayer Pharma v Farbenfabriken Bayer AG [1965] HCA 71, (1965) 120 CLR 285 at 323 per Barwick CJ.

50 Trade Marks Act 2002, s 47.

51 Trade Marks Act 2002, s 73. For a discussion of the term "aggrieved person" see generally RJ Batty and RC Watts "Aggrieved No More: Is There a Need for Standing to Remove Unused Trade Marks?" [2013] NZ L $\operatorname{Rev} 1$. 
A person seeking invalidation of a registered trade mark has the onus of rebutting its validity on the grounds of prior use. ${ }^{52}$ In an opposition, the onus usually lies on the trade mark applicant to establish that its mark does not offend against one of the absolute or relative grounds in the 2002 Act. ${ }^{53}$ However, in an ownership context, it is better to view the onus as neutral and it will usually be up to an opponent to establish a positive use that pre-dates the application date. ${ }^{54}$ Often it will be unnecessary for an opponent or cancellation applicant who considers it has pre-existing rights in an unregistered mark to establish it is the "owner" of the trade mark. The 2002 Act, and the structure of trade mark law generally, is able to address concerns about the prior use of a trade mark in a number of ways.

First, s 17(1)(a) of the 2002 Act enables a person who has acquired a reputation in the marketplace associated with an unregistered trade mark to oppose a subsequent trade mark application on the basis of a likelihood of confusion. The standard of reputation required is relatively low as it only requires an awareness, cognisance or knowledge of the mark by a substantial number of persons in the relevant market. ${ }^{55}$ The object of s 17(1)(a) is to protect the public from confusion, rather than the proprietary interests of a trader. ${ }^{56}$ Yet, given s 17(1)(a)'s focus on confusion, it is able to address a great majority of claims involving prior use of the same or similar trade mark. Section 17(1)(a) has a broad scope that is able to take into account spill-over reputation from overseas. ${ }^{57}$ Furthermore, it is also not necessary for there to be identity between marks $^{58}$ or goods/services. ${ }^{59}$

In Pioneer Hi-Bred Corn Company v Hy-Line Chicks Pty Ltd (Pioneer), the Court of Appeal addressed the fate of the application of the HY-LINE mark on the basis of an equivalent section to $\mathrm{s}$ 17(1)(a) rather than on grounds of ownership. ${ }^{60}$ The Court of Appeal held that, at the date of

52 See Advantage Computers Ltd v Advantage Group Ltd HC Auckland CL41/99, 28 June 2002 at [32] citing Philip Morris (NZ) Ltd v Liggett \& Myers Tobacco Co (No 3) (1978) 1 NZIPR 195 (SC) at 204.

53 See Pioneer Hi-Bred Corn Company v Hy-Line Chicks Pty Ltd [1978] 2 NZLR 50 (CA) at 61 [Pioneer].

54 See Valley Girl Co Ltd v Hanama Collection Pty Ltd (2005) 66 IPR 214 (HC) at [35] "To establish proprietorship, either party must satisfy these three requirements" (emphasis added).

55 N V Sumatra Tobacco Trading Co v British American Tobacco (Brands) Inc [2010] NZCA 24, (2010) 86 IPR 206 at [77].

56 Pioneer, above n 53, at 63 per Richardson J.

57 Pioneer, above $\mathrm{n} 53$, at 53-54 per Richmond $\mathrm{P}$, at 58 per Woodhouse $\mathrm{J}$, and at 70 per Richardson $\mathrm{J}$.

58 See for example $N$ V Sumatra Tobacco Trading Co v British American Tobacco (Brands) Inc, above n 55 (LUCKY STRIKE versus LUCKY DREAM and LUCKY DRAW).

59 See for example Fonterra Brands (Tip Top Investments) Ltd v Tip Top Restaurant Ltd, above n 35 (services for providing food and drink versus ice cream products).

60 Pioneer, above $\mathrm{n} 53$, only Woodhouse $\mathrm{J}$ addressed in any detail the proprietorship issue that had been raised before the Assistant Commissioner. 
application, the evidence established that the HY-LINE mark was known to a substantial number of persons in the New Zealand poultry industry. As a result of this reputation, the Court of Appeal found there was risk of confusion and upheld the lower court's rejection of the trade mark application. ${ }^{61}$ Similarly, in Red Bull v Meier Baragwanath J had to consider Red Bull's opposition to a trade mark application for BULL RUSH on the basis of consumer confusion and on ownership grounds. ${ }^{62}$ Baragwanath J suggested that claims of ownership may "divert ... attention from the real issue", ${ }^{63}$ and rejected the application for BULL RUSH on the basis of consumer confusion. ${ }^{64}$

Secondly, s 25(1)(c) prohibits the registration of a mark which is identical or similar to a wellknown mark where use of the mark applied for would be taken as indicating a connection in the course of trade with the owner of the well-known mark, and would be of prejudice to the owner. Section 25(1)(c) contemplates a mark may be well-known through advertising or other means, indicating that it is not necessary for the mark to be used or registered in New Zealand. Thus, a trader may be able to establish that its mark is well-known and succeed in an opposition rather than establishing it is the owner.

Thirdly, s 17(2) of the 2002 Act provides that "the Commissioner must not register a trade mark if the application is made in bad faith". An objection ground of bad faith has its origins in European trade mark law and was inserted into the Trade Marks Act 1994 (UK) from the European Community Trade Mark's Directive. ${ }^{65}$ Some United Kingdom courts have interpreted "bad faith" as being premised on some degree of commercial dishonesty on the part of the applicant in applying for a trade mark or conduct falling short of acceptance commercial behaviour. ${ }^{66}$ Others have used a yardstick of reprehensible conduct. ${ }^{67}$ In Neumann $v$ Sons of the Desert Andrews J, after citing United Kingdom case law, said the court must decide, taking into account the knowledge of the applicant, whether "its decision to apply for registration would be regarded as being in bad faith by a person adopting proper standards". ${ }^{68}$ It could be argued that the bad faith ground would capture

61 Pioneer, above $\mathrm{n} 53$, at 53 per Richmond $\mathrm{P}$, at 58 per Woodhouse $\mathrm{J}$, and at 76 per Richardson $\mathrm{J}$.

62 Red Bull v Meier [2002] FSR 42 (HC).

63 At [47] referring to comments made in Pioneer Hi-Bred Corn Company v Hy-Line Chicks Pty Ltd, above $\mathrm{n}$ 53 , at 63 per Richardson $\mathrm{J}$.

64 Red Bull v Meier, above n 62, at [63].

65 The First Council Directive 89/104 (21 December 1988) to approximate the laws of the Member States relating to trade marks. Now replaced by Directive 2008/95/EC of the European Parliament and the Council (22 October 2008) to approximate the laws of the Member States relating to trade marks (Codified version). See also Paul Sumpter "Section 62A: Pandora's Box for Trade Mark Practitioners?" (2007) 18 AIPJ 110 at 114

66 Gromax Plasticulture Limited v Don \& Low Nonwovens Limited [1999] RPC 367 at 379.

67 DAAWAT Trade Mark [2003] RPC 187 at 204.

68 Neumann v Sons of the Desert HC Auckland CIV-2007-485-212, 5 November 2007 at [33]. 
many cases of deliberate misappropriation and possibly sweep up cases not falling within s 17(1)(a) or s $25(1)(c)$.

Despite the overall scope of ss 17(1)(a), 17(2) and 25(1)(c), there are some situations where a challenge to ownership may have work to do. There may be a situation where there has been use of a trade mark, but there is no existing reputation in the local marketplace associated with that mark. Before there is any prospect of confusion or deception arising through use of a mark under $\mathrm{s}$ 17(1)(a) or some form of trade connection under s 25(1)(c) there must be some awareness of the earlier trade mark. ${ }^{69}$ As we will see, ownership challenges are not dependent on reputation in the marketplace. Similarly, there may be situations where there has been prior use of a trade mark, but such use has ceased for a period of time such that there is no longer any reputation or awareness in the mark. Moreover, the bad faith ground will not necessarily sweep up such situations. Case law suggests that bad faith normally requires some form of knowledge. ${ }^{70}$ As Sumpter has argued, "it is difficult to see how it applies to the ignorant but honest applicant". ${ }^{71}$ Finally, there may be situations where there are challenges by third parties who themselves have no interest in establishing ownership of the mark. Rather ownership may be put in issue to invalidate a mark as a cross-claim in an infringement action. ${ }^{72}$ In the next part, I examine the statutory grounds of the 2002 Act under which ownership is put in issue.

\section{STATUTORY PROVISIONS ADDRESSING OWNERSHIP ON THE BASIS OF PRIOR USE}

\section{A Proprietorship Jurisprudence under the 1953 Act}

There is no explicit ground on which to challenge ownership under the 2002 Act. Nevertheless, judges, and adjudicators at IPONZ, have followed jurisprudence under the previous Trade Marks Act 1953 (1953 Act) and permitted common law claims to "proprietorship" based on prior use. Section 26(1) of the 1953 Act provided that:

69 See Pioneer, above n 53, at 63:

... if the opponent's mark is wholly unknown in the New Zealand market in which the applicant's mark is proposed to be used, the use of the applicant's mark could not lead to deception or cause confusion.

70 See for example DAAWAT Trade Mark, above n 67, where a "vague suspicion" that the owner of a mark overseas may have wanted to extend its trade into the United Kingdom was not sufficient to support a claim of bad faith.

71 Paul Sumpter Intellectual Property Law: Principles in Practice (CCH, Auckland, 2006) [Sumpter 1st ed] at 144. Compare Paul Sumpter Intellectual Property Law: Principles in Practice (2nd ed, CCH, Auckland, 2013) at 150 .

72 See for example Global Brand Marketing Inc v YD Pty Ltd [2008] FCA 605, (2008) 76 IPR 161 (unsuccessful) referred to in Television Food Network, GP v Food Channel Network Pty Ltd (No 2) [2009] FCA 271 at [31]. 
any person claiming to be the proprietor of a trade mark used or proposed to be used by him who is desirous of registering it shall apply in writing to the Commissioner ...

In North Shore Toy Co v Charles L Stevenson Ltd (North Shore Toy), McMullin J relied on English authority to posit that a person putting forward an application claiming to be the proprietor had to be in possession of a substantiated right to the trade mark. ${ }^{73}$ On the facts of that case, it was found that a distributor was not entitled to assert it was the proprietor of the mark. ${ }^{74}$ This finding was informed by the starting point that common law proprietorship was established by use. ${ }^{75}$ McMullin $\mathrm{J}$ thought that this proposition was undisturbed by the introduction of trade mark legislation. ${ }^{76}$

In Red Bull v Meier, Baragwanath $\mathrm{J}$ was less certain that a trader should be able to use common law prior use rights to challenge a registration given that the 1953 Act had explicitly removed any cause of action for owners of unregistered marks. ${ }^{77}$ However, courts, ${ }^{78}$ IPONZ decisions, ${ }^{79}$ and opinions of textbook writers consistently expressed the view that proprietorship could be challenged under s 26 relying on common law principles. ${ }^{80}$ In Newnham v Table for Six (1996) Ltd, Cartwright $\mathrm{J}$ suggested that the requirements for a legitimate claim to proprietorship were threefold: ${ }^{81}$

(1) There is no prior use or assertion of proprietorship.

(2) The applicant is using or has a sufficiently definite intention to use the mark.

(3) There is no fraud or breach of duty involved.

These requirements have been routinely cited in subsequent case law and were approved in Aqua Technics Pool and Spa Centre New Zealand Ltd v Aqua-Tech Ltd (Aqua Technics), where the

73 North Shore Toy Co Ltd v Charles L Stevenson Ltd, above n 11, at 571 citing Re Vitamins Ltd's Application [1956] 1 RPC 1 at 12.

74 North Shore Toy Co Ltd v Charles L Stevenson Ltd, above n 11, at 572-573.

75 At 567 .

76 At 567 .

77 Red Bull v Meier, above n 62, at [48].

78 Pioneer Hi-Bred Corn Company v Hy-Line Chicks Pty Limited, above n 47; Newnham v Table for Six (1996) Ltd (1998) 44 IPR 269 (HC).

79 Dutch Boy's Paint Co Limited v National Lead Company [1973] NZIPOTM 3 (26 June 1973) and Melco New Zealand Limited v Oasis Corporation [2002] NZIPOTM 42 (15 August 2002).

80 See Brown and Grant, above n 39, at [2.8].

81 Newnham v Table for Six (1996) Ltd, above n 78, at 278 citing Brown and Grant, above n 39, at [2.8]. 
Court of Appeal also confirmed that the "proprietor of a trade mark in New Zealand is the first person to use that mark in New Zealand". ${ }^{82}$

\section{B Does the Common Law of Proprietorship Based on Prior Use Apply under the 2002 Act?}

When the 2002 Act was first passed, the opening words of s 32(1) stated "a person may, on payment of the prescribed fee (if any), apply in the prescribed manner ...". Unlike the wording of $s$ 26 of the 1953 Act, s 32(1) did not mention "owner" or "proprietor". Moreover, the 2002 Act introduced a number of new concepts and provisions, borrowing heavily from the trade mark legislation of both Singapore and the United Kingdom, which in turn were influenced by European trade mark law harmonisation. The trade mark legislation of Singapore and the United Kingdom do not expressly state there is a limitation on who may apply for a trade mark application (although both require an applicant to have a bona fide intention to use the trade mark applied for). Some commentators initially argued that the wording of s 32 indicated that this section did not deal with "proprietorship". 83

The interpretation that s 32 did not regulate proprietorship was strengthened by the introduction into the 2002 Act of a bad faith ground of objection. Some of the literature considered that it was this bad faith provision that was designed to "capture bad claims to ownership", including cases of prior use ${ }^{84}$ Practice at the registry level was mixed. In some oppositions and invalidation actions at IPONZ ownership by virtue of prior use was put into issue on the basis of bad faith. ${ }^{85}$ Other oppositions and invalidation actions where ownership was at issue were decided on the basis of $\mathrm{s}$ $32 .{ }^{86}$

82 Aqua Technics Pool and Spa Centre New Zealand Ltd v Aqua-Tech Ltd [2007] NZCA 90 at [14] referring to Philip Morris (NZ) v Liggett \& Myers Tobacco Co (NZ) Ltd (No 3), above n 52.

83 Paul Sumpter Trade Marks in Practice (LexisNexis, Wellington, 2004) at [TMA 32.3]. Compare Kiwicare Corporation Limited $v$ Advanced Formulations (Europe) Limited [2008] NZIPOTM 20 (4 August 2008) at [51] where it was stated that the wording of s 32 still implied "that a person applying for a trade mark registration is claiming to be the owner of the mark or else it would be improper for the person to apply for registration".

84 Paul Sumpter "Bad Faith and Ownership: Some Observations on the Trade Marks Acts of Australia and New Zealand" (2005) 4 NZIPJ 118 at 120: "With its European remodelling, the question of disputed ownership in the NZ Act then became reliant solely on the bad faith provision." Sumpter, above $n$ 83, at [TMA 17.10]. Finch, above n 40, at 463. Sumpter 1st ed, above n 71, at 144-147.

85 See for example Zhongshan Juxiangyuan Food Co Ltd v Choi Heong Yuen-Macau Limited [2006] NZIPOTM 8 (8 May 2006) and Guan Sheng Yuan (Group) Co Ltd v Tien Chu (Hong Kong) Co Limited [2008] NZIPOTM 25 (15 September 2008).

86 See for example McPhail Sports Limited $v J \&$ \& Fashions Pty Limited [2005] NZIPOTM 32 (4 January 2006) (invalidity). 
Further obscuring matters, in one IPONZ decision it was stated that a proprietorship challenge based on prior use is "better dealt with under the 'contrary to law and disentitled to protection' ground", rather than on the bad faith ground. ${ }^{87}$ Section 17(1)(b) of the 2002 Act provides that a mark must not be registered "the use of which is contrary to New Zealand law or would otherwise be disentitled to protection in any court". In North Shore Toy McMullin J considered an almost identical provision under the 1953 Act. McMullin J observed that the contrary to law provision may have been intended to "prohibit the use of marks which were the common law property of another". ${ }^{88}$ McMullin J also thought that: ${ }^{89}$

a trade mark which has been registered as a result of the wrongful assertion of a claim to proprietorship

is a trade mark which would not be entitled to protection in a Court of justice.

Some clarity was seemingly provided in 2005 when Parliament amended s 32 to state that an application can be made by a "person claiming to be the owner of a trade mark". 90 This amendment was to clarify "that it is the owner of the trade mark who applies for its registration".91 The changed reference in s 32 to "owner", established a closer link to s 26 of the 1953 Act. The term "owner" is defined to include a person who owns all the rights in the mark (for unregistered trade marks). ${ }^{92}$ Thus, the amendment to s 32 appeared to confirm that the prior user of a trade mark could put proprietorship of a trade mark into issue via s 32 .

The amendment to s 32 left some issues unresolved. It did not elucidate what "claiming to be owner" meant. Did it mean that the trade mark applicant must have a subjectively honest claim to ownership - meaning that as long as an applicant did not know about any instances of prior use or prior adoption of the mark, its claim would be valid? Or did it mean the trade mark applicant must have an objectively valid claim to ownership - meaning that knowledge was irrelevant?

The amendment to s 32 also left the role of the bad faith and contrary to law grounds in respect of prior use claims unclear. The better view may be that bad faith is directed at a different mischief than merely prior use, ${ }^{93}$ and as a result is not designed to capture cases of innocent adoption.

87 The Derek Corporation Ltd v DC Buck and T J Manuell [2006] NZIPOTM 22 (25 September 2006).

88 North Shore Toy Co Ltd v Charles L Stevenson Ltd, above n 11, at 572. See also Wham-O MFG v Lincoln Industries Ltd [1981] 2 NZLR 628 (HC) at 657.

89 North Shore Toy Co Ltd v Charles L Stevenson Ltd, above n 11, at 572.

90 See Trade Marks Amendment Act 2005, s 6.

91 Statutes Amendment Bill (No 5) 2005 (249-2) (explanatory note).

92 Trade Marks Act 2002, s 5.

93 For example this seems to have been the legislative intent when Australia amended its trade marks law to introduce a bad faith ground of opposition. The Explanatory Memorandum to the Trade Marks Amendment Bill 2006 (Cth) at [4.12] intimated that a bad faith ground of opposition was needed because the existing "ownership" ground of opposition in the Trade Marks Act 1995 (Cth) did not cover situations such as where 
However, it is not so clear that the contrary to law ground is intended to be so restricted. If a mark belongs at common law to another, then it could be argued that registration would be contrary to law or disentitled to protection regardless of the applicant's or registrant's knowledge.

A further problematic issue was ascertaining the correct ground to plead in an invalidation proceeding based on prior use. Section 73 enables a mark to be declared invalid if it should never have been registered according to the criteria in pt 2 of the 2002 Act. However, s 32 is not in pt 2, but in pt 3 of the 2002 Act. For this reason, it was suggested by some that ownership challenges based on s 32 could not be brought under s $73 .{ }^{94}$ It would instead be necessary to sheet home the prior use challenge under the bad faith or contrary to law provisions in pt 2 of the 2002 Act.

\section{$C$ Chettleburgh v Seduce Group}

The precise scope of s 32 and its application both to opposition and invalidation actions in terms of proprietorship now appears settled following Chettleburgh v Seduce Group (Chettleburgh) ${ }^{95}$ An Australian company, Seduce Group, made an application to invalidate the SEDUCE mark registered to $\mathrm{Mr}$ Chettleburgh in respect of women's fashion clothing. Seduce Group had sold women's clothing to a New Zealand importer over a two year period prior to Mr Chettleburgh's application. Mr Chettleburgh was not aware of SEDUCE clothing ever being made available in New Zealand prior to filing his application. However, the Assistant Commissioner was satisfied that Seduce Group had made prior use and declared Mr Chettleburgh's trade mark invalid. ${ }^{96} \mathrm{Mr}$ Chettleburgh appealed. His arguments on appeal included that in considering an application for a declaration of invalidity under s 73(1), the Commissioner or Court cannot rely on s 32 to argue that the person applying for the mark was not the true owner of the mark.

In the High Court, Woodhouse $\mathrm{J}$ confirmed a person may oppose a trade mark application on the basis of prior use via s $32 .{ }^{97}$ Woodhouse $\mathrm{J}$ then interpreted s 32 as requiring some substance to support the claim of ownership. In other words, Woodhouse J rejected that "claiming to be owner" in s 32 was a formality that simply mandated that an application be accompanied by a statement of claimed ownership, with merit being irrelevant. Woodhouse $\mathrm{J}$ expressed the view that having substance to the claim meant that "it must be one that is capable of being established as valid". ${ }^{9}$

a person has set out deliberately to gain registration by way of underhand dealings, such as monitoring new property developments and registering the name of the property development as a trade mark.

94 Laws of New Zealand Intellectual Property: Trade Marks (Reissue 1) at [182]. Compare Laws of New Zealand Intellectual Property: Trade Marks (online ed) at [182].

95 Chettleburgh v Seduce Group Australia Pty Ltd [2012] NZHC 2563, (2012) 98 IPR 306 [Chettleburgh].

97 Chettleburgh, above n 95, at [38].

98 At [40]. 
Woodhouse $\mathbf{J}$ drew support for the notion that a claim to ownership under s 32 must be a valid claim by reference to the dictionary definitions of the word "claim" which he suggested connoted that a claim must have substance. ${ }^{99}$ Woodhouse $\mathrm{J}$ also found support in the legislative history of $\mathrm{s}$ 32 which suggested that Parliament intended that the law concerning proprietorship under the 1953 Act should continue to be applied to the 2002 Act. Woodhouse J cited Aqua Technics for the proposition that a claim to proprietorship under s 26 of the 1953 Act must be a legitimate claim. Woodhouse $\mathrm{J}$ stated that he was satisfied that case law under the 1953 Act in respect of s 26 applied to the 2002 Act. ${ }^{100}$

In the course of his judgment, Woodhouse $\mathbf{J}$ noted that it could be argued that the bad faith ground of objection sufficiently defines the scope of ownership challenges. ${ }^{101}$ However, Woodhouse J thought that approaching ownership on the basis of bad faith would limit the scope of s $32 .{ }^{102}$ In Woodhouse J's view some form of assessment of the merit of an applicant's claim to ownership of the mark is required. Accordingly, even if an applicant filed an application claiming and genuinely believing to be the owner of the trade mark, the application or registration could be challenged on the basis that, as a matter of fact, another person is the true owner of the trade mark. ${ }^{103}$

When considering the argument that ownership could not be challenged in invalidation proceedings, Woodhouse J placed focus on s 13(2)(a) which provides that an application must be made in accordance with the 2002 Act. Section 13 is in pt 2 of the 2002 Act. Woodhouse J reasoned that s 32 was one of the requirements that needed to be adhered to in evaluating s 13(2)(a). Thus, reading ss 73, 13 and 32 in sequence meant that a s 32 claim to ownership could be brought in a s 73 invalidation proceeding. ${ }^{104}$ Woodhouse $\mathrm{J}$ reverted the matter back to the Assistant Commissioner to decide again, as other issues needed to be considered.

\section{Summary and Assessment of Law Under the 2002 Act}

Chettleburgh has confirmed that a trade mark can be opposed and invalidated on the basis of $\mathrm{s}$ 32 on the ground that at the date of application the trade mark applicant was not the true owner of the trade mark because there had been prior use. Some prior users also continue to rely on bad faith and the "contrary to law and disentitled to protection" provisions as a route to challenge ownership

99 At [35].

100 At [49].

101 At [42].

102 At [42].

103 At [43].

104 At [31]. 
based on prior use. ${ }^{105}$ However, framing a prior use challenge based on s 32, rather than bad faith, may be more attractive to a prior user as it potentially enables a registration to be invalidated or an application opposed, where the registrant or applicant was ignorant of such prior use.

The route to challenge ownership on the basis of prior use through s 32, though, appears cumbersome. Unlike in Australia, where the trade mark legislation clearly identifies ownership as a ground of opposition, ${ }^{106} \mathrm{~s} 32$ is not located with the other absolute and relative grounds to oppose an application. In terms of an invalidation proceeding, Woodhouse J's linking of s 73 to s 13 (in pt 2 of the 2002 Act) may have been logically sound. However, it is a rather tortuous interpretation. Finally, application of s 32 relies on a proprietorship test developed at common law which is divorced from the wording of s 32 . The wording of s 32 does not capture the notion that ownership may be challenged if there has been prior use of the same mark.

Finally, prior to Chettleburgh there was a suggestion in a number of IPONZ hearings that it was unnecessary to plead a specific section of the 2002 Act to put ownership of a trade mark in issue. ${ }^{107}$ In Chettleburgh Woodhouse J gave this interpretation short shrift. Relying on the provisions of the Trade Mark Regulations and earlier case law, Woodhouse $\mathrm{J}$ held that an express statement of a particular ground of opposition or invalidation was mandatory. ${ }^{108}$ As there is no limit on the number of grounds pleaded in an opposition or invalidation proceedings, the effect is likely to be an increase in the incidence of prior use challenges based on s 32 .

\section{THE LAW OF PROPRIETORSHIP ON THE BASIS OF PRIOR USE}

\section{A Prior Use of a Trade Mark}

When a trader disputes ownership on the basis of prior use, the main issue is whether there is evidence of actual "use" of the mark which predates the date the application was filed. Determining priority by ascertaining when use occurred cannot be resolved without determining what activities constitute "use" of the mark. The oft cited case of Moorgate Tobacco Co Ltd v Philip Morris Ltd

\footnotetext{
105 See for example Anaforza Ltd v Dimes Gida Sanayi Ve Ticaret Anonim Sirketi [2013] NZIPOTM 21 (11 June 2013) (invalidation action).

106 Trade Marks Act 1995 (Cth), s 58.

107 See Transworld International Trading Limited v Northwest Natural Products Inc [2011] NZIPOTM 8 (11 May 2011) at [5]-[8] referring to Husssh Silencers v Gun City Ltd [2010] NZIPOTM 10 (31 May 2010) at [17.1].

108 Chettleburgh, above n 95, at [66].
} 
(No 2) (Moorgate) is a useful starting point. ${ }^{109}$ In Moorgate the Australian High Court emphasised that prior use in a proprietorship sense must be public use of a mark as a trade mark in Australia. ${ }^{110}$

"Trade mark" is defined in the 2002 Act to mean a sign capable of distinguishing the goods of one person from those of another. ${ }^{111}$ Section 6 defines "use of a sign in relation to goods" to include the use of the sign on, or in physical or other relation to, goods. "Other relation to" is a broad concept. It encompasses use beyond affixation of a sign on goods, and includes the presence of a sign in advertisements, orders or invoices. ${ }^{112}$ For example, in Aqua Technics it was accepted that the use of a sign could be on promotional materials and not on the goods themselves. ${ }^{113}$

Not every presence of a sign on, or in relation to, goods will amount to use of a trade mark. The concept of "capable of distinguishing" in the definition of trade mark incorporates the function of a trade mark as a badge of origin. ${ }^{114}$ Where an adjudicator considers that consumers will not see a sign as an indicator of source, the use will not qualify. This could be where the sign is perceived as decorative or descriptive. For example, in Effem Foods $v$ Cadbury the use of EARTH was ultimately not considered trade mark use because it was not used to indicate trade origin - the EARTH mark was found to be "a clever way of advertising the MARS bar". ${ }^{115}$ The thrust of the advertising was not to indicate trade source but to juxtapose EARTH with the established trade mark MARS.

The notion of "public use" outlined in Moorgate also intimates that the presence of a sign that makes a communication about the origin of goods or services must have some external exposure to the marketplace. Broadly speaking, the courts have drawn a distinction between preliminary activities and activities which are commensurate with actual trade or an offer to trade in the goods bearing the trade mark. For example, in Moorgate cigarette packets and advertising material bearing

109 Moorgate Tobacco Co Ltd v Philip Morris Ltd [1984] HCA 73, (1984) 156 CLR 415 [Moorgate]; Moorgate is cited routinely by New Zealand courts, see for example Aqua Technics Pool and Spa Centre New Zealand Ltd v Aqua-Tech Ltd, above n 82, at [17].

110 Moorgate, above n 109, at [21].

111 Trade Marks Act 2002, s 5.

112 Finch, above n 40, at 574. See also Paul Sumpter Trade Marks in Practice (2nd ed, LexisNexis, Wellington, 2011) at [TMA6.4])

113 Aqua-Tech Ltd v Aqua Technics Pool \& Spa Centre NZ Ltd HC Auckland CIV-2005-404-2037, 3 October 2005 at [29]. Not disturbed on this point on appeal in Aqua Technics Pool and Spa Centre New Zealand Ltd $v$ Aqua-Tech Ltd, above n 82. Similarly in Effem Foods Ltd v Cadbury Ltd, above n 8, at [23] it was observed that use of a sign on television advertisements, rather than on the goods themselves, could potentially qualify as use.

114 See for example the comments in Anheuser-Busch Inc v Budweiser Budvar National Corporation [2003] 1 NZLR 472 (CA) at [97]-[101] and E \& J Gallo Winery v Lion Nathan Australia Pty Ltd [2010] HCA 15, (2010) 241 CLR 144 at [42].

115 Effem Foods Ltd v Cadbury Ltd, above n 8, at [27]. 
the trade mark KENT GOLDEN LIGHTS had only been sent to representatives of Philip Morris in Australia. It was held that these activities were merely negotiations and preliminary discussions about the use of the KENT GOLDEN LIGHTS mark. They were not "any actual trade or offer to trade in goods bearing the mark in Australia" and therefore Moorgate Tobacco Co Ltd was not able to establish prior use. ${ }^{116}$

Ascertaining where the line is to be drawn between merely preparatory or preliminary activities and actual trade is not always easy. Most commonly the issue is put into focus when there is doubt as to whether overseas use has stretched into the relevant jurisdiction. It is well established that it is open for a trader to become the valid owner of a trade mark that has been used overseas, even extensively, provided it has not been used in New Zealand. ${ }^{117}$ The courts have said that it may be sharp business practice, but it is not unlawful. ${ }^{118}$ However, in Seven UP Company $v$ OT Limited Williams $\mathbf{J}$ also observed the court "frowns upon" attempts at appropriation and "therefore seizes upon a very small amount of use" to support the case of a prior user. ${ }^{119}$

The "seizing on a small amount of use" in deliberate cases of misappropriation of overseas marks has subsequently been applied in cases where there is no question of "piracy" on the part of trade mark applicants. ${ }^{120}$ The result being that a prior user need only meet a very low threshold in terms of sufficiency of use to found a proprietorship claim. For example, in Thunderbird Corporation v Thunderbird Marine Products Ltd the Australian High Court held that, although the use relied upon was essentially a single sale, the American company was the first to use the mark to distinguish its goods. ${ }^{121}$ Australian case law has been routinely cited by New Zealand courts for the proposition that a low standard of use is sufficient to found a claim of prior use. ${ }^{122}$

The low standard of use is complemented by the fact that the presence of a trade mark in advertising is generally considered use of a trade mark in the course of trade. In Malibu Boats West Inc $v$ Catanese Finkelstein $\mathrm{J}$ explained that "this is because an advertisement is a common method of indicating that certain goods are available for sale and that the vendor is soliciting orders for

116 Moorgate, above n 109, at [23]

117 See for example Automobile Club de L'Ouest ACO v South Pacific Tyres New Zealand Ltd HC Wellington CIV-2005-485-248, 23 March 2006 citing Seven UP Company v OT Limited, above n 41, at 211.

118 Re Registered Trade Mark "Yanx" [1951] HCA 28, (1951) 82 CLR 199 at 202 [Re Yanx].

119 Seven UP Company v OT Limited, above n 41, at 211.

120 M Davison and I Horak Shanahan's Australian Law of Trade Marks and Passing Off (5th ed, Lawbook Co, Sydney, 2012) at [10.520].

121 Thunderbird Products Corp v Thunderbird Marine Products Pty Ltd [1974] HCA 51, (1974) 131 CLR 592 at 602 .

122 See for example Aqua Technics Pool and Spa Centre New Zealand Limited v Aqua-Tech Limited, above $\mathrm{n}$ 82, at [46] citing Thunderbird Products Corp v Thunderbird Marine Products Pty Ltd, above n 121. 
those goods". ${ }^{123}$ Advertising in the absence of any form of trade is not sufficient. ${ }^{124}$ Advertising in foreign publications not in circulation in New Zealand, ${ }^{125}$ or not directed to the New Zealand marketplace, will also not qualify. ${ }^{126}$ However, where a trade mark has been exposed to the marketplace in an advertisement circulating in a jurisdiction, the courts have been willing to find use where it is possible to identify an existing intention to offer or supply goods bearing the trade mark. ${ }^{127}$ Thus, a magazine containing an advertisement for goods circulating in New Zealand has been found to be sufficient to constitute prior use. ${ }^{128}$

The courts' approach to advertising means that it is not necessary for there to be actual sales of goods bearing the mark in the New Zealand marketplace to constitute use. ${ }^{129}$ In Re Yanx it was found there had been prior use where goods had been despatched to Australia, but had not yet arrived in Australia. ${ }^{130}$ Further, in perhaps a high water mark, it was held in the Australian case of Buying Systems $v$ Studio SrL that obtaining business cards, the printing of letterheads and approaching potential advertisers to solicit the placing of advertisements in a new magazine were sufficient - even though the magazine itself was not in existence. ${ }^{131}$ The key appears to be that the trader had demonstrated an existing intention to offer, or supply, the magazine in trade. ${ }^{132}$

\section{B Identity of Marks and Same Kind of Goods}

While there is plainly a low standard of use, a prior user is required to demonstrate it has used an identical mark in respect of the same goods. The Australian approach has been to require identity or "substantial identity" between marks. ${ }^{133}$ To assess substantial identity, marks are usually

123 Malibu Boats West Inc v Catanese [2000] FCA 1141, (2000) 51 IPR 134 at [34].

124 HERMES Trade Mark [1982] RPC 425 at 430.

125 Pioneer, above n 53, at 56 per Richmond P; Melco New Zealand Limited v Oasis Corporation, above n 79, citing Malibu Boats West Inc v Catanese, above n 123.

126 Valley Girl Co Ltd v Hanama Collection Pty Ltd, above n 54, at [42].

127 See in particular Re Yanx, above n 118, at [6]; Moorgate, above n 109, at [23].

128 The Derek Corporation Ltd v DC Buck and T J Manuell, above n 87.

129 See Melco New Zealand Limited v Oasis Corporation, above n 79, referring to Moorgate, above n 109 , Settef SpA v Riv-Oland Marble Co (Vic) Pty Ltd (1987) 10 IPR 402 and Re Yanx, above n 118.

$130 \operatorname{Re}$ Yanx, above n 118, at [6].

131 Buying Systems (Aust) Pty Ltd v Studio SrL [1995] FCA 1063, (1995) 30 IPR 517.

132 At 520 .

133 This approach has been followed by IPONZ, see for example New Balance Athletic Shoe Inc $v$ International Stars SA [2012] NZIPOTM 9 (5 April 2012) at [59]. 
compared visually side by side to assess the total impression that emerges. ${ }^{134}$ Substantial identity under Australian law is a strict test. For example, in Carnival Cruise Lines v Sitmar Cruises, Gummow J considered the trade mark FUNSHIPS was not substantially identical to SITMAR'S FUNSHIP or FAIRSTAR THE FUN SHIP. ${ }^{135}$ New Zealand legal authority on the issue of identity has been sparse. In The North Face Apparel Corp v Sanyang Industry Co Ltd, Collins J had to compare two device marks and started by referring to the strict Australian approach. ${ }^{136}$ However, Collins $\mathbf{J}$ thought there was room under the substantial identity test to compare marks visually, aurally and conceptually. ${ }^{137}$

It remains to be seen whether a broader approach will be followed in future cases. One could posit a situation involving the comparison of two device marks where it may be open for an opponent to offset visual dissimilarity by pointing to a high degree of conceptual identity. Such an approach, though, may create a danger that an earlier adopter of a certain motif or theme may gain a quasi-monopoly over that motif or theme. Such an approach may also present practical difficulties. Working out whether two marks are visually or aurally identical (or substantially identical) is tolerably predictable. However, assessing conceptual similarity can be difficult as it is dependent on the level of generality at which one identifies the concept or idea of a mark. ${ }^{138}$

The prior user of an identical or substantially identical unregistered trade mark does not have "rights at large in relation to the mark". ${ }^{139}$ The prior user's rights are constrained in scope to rights for the "same" goods for which the mark was used. An oft cited case in this area of law is In Re Hicks Trade Mark. ${ }^{140}$ Holroyd J said that prior use of the "same word in application to the same kind of thing" could interfere with a claim to proprietorship. ${ }^{141}$ Whether goods are the same kind of thing or not can be obfuscated by the descriptions given to goods. For example, would an application to register a trade mark for confectionery be effectively "trumped" by prior use of the same mark for chocolate biscuits? Later Australian cases suggested a common sense approach to try to find "the true equivalent kind of thing or article". ${ }^{42}$ While reasonable minds may disagree about

134 See Shell Companies of Australia Ltd v Esso Standard Oil (Australia) Ltd (1963) 109 CLR 407 at 414 per Windeyer J.

135 Carnival Cruise Lines v Sitmar Cruises [1994] FCA 936, (1994) 31 IPR 375.

136 The North Face Apparel Corp v Sanyang Industry Co Ltd [2012] NZHC 2259.

137 At [40]-[41].

138 See Elwood Clothing Pty Ltd v Cotton On Clothing Pty Ltd [2008] FCAFC 197, (2008) 80 IPR 566 at [35] discussing the difficulties of the idea/expression dichotomy in the law of copyright.

139 Colorado Group Ltd v Strandbags Group Pty Ltd (2007) FCR 506, (2007) FCAFC at [6] per Kenny J.

140 In Re Hicks' Trade Mark (1897) 22 VLR 636.

141 At 640

142 Colorado Group Ltd v Strandbags Group Pty Ltd, above n 139, at [89] per Allsop J. 
cases at the margins, ${ }^{143}$ determining the sameness of goods has not proved, to date, to be a highly contentious issue. However, as the next part will demonstrate, other elements of the law of proprietorship operate unsatisfactorily within the context of a registered trade mark system.

\section{WHY THE LAW OF PROPRIETORSHIP BASED ON PRIOR USE DOES NOT FIT WELL WITH THE TRADE MARK SYSTEM}

\section{A Doctrinal Misalignment}

A questionable element of the current law of proprietorship based on prior use is that there is no de minimis threshold regarding the sufficiency of use necessary to substantiate a claim. A second related issue is that there appears to be no (or at least, expressed) limit as to how far back in time a prior user may go to establish a claim for proprietorship based on prior use. The low standard and lack of temporal limit is arguably misaligned with the current law of unregistered trade marks.

Misalignment arguably stems from the leading case law's reliance on 19th century cases for the proposition that it is unnecessary for a general market reputation to exist to substantiate a claim of proprietorship based on prior use. ${ }^{144}$ This case law represents a property orientated view of unregistered trade marks. In an oft cited case, Hall $v$ Barrows, Romily MR observed "... I apprehend, although the mark may not have been adopted a week, and may not have acquired any reputation in the market, his neighbours cannot use that mark". ${ }^{145}$ On appeal, Lord Westbury did not interfere with Romily MR on this point and reiterated his view "that the jurisdiction of the Court in the protection of trade marks rests upon property". 146

Linked to a low threshold, application of 19th century case law suggests that, absent a clear indication of abandonment, a prior user can rely on historical use even after it has ceased making use of the trade mark. ${ }^{147}$ In Mouson \& Co v Boehm it was held that abandonment required an intention on the part of the trade mark owner to relinquish its rights in the mark. ${ }^{148}$ It was observed

143 See the different approaches of Kenny $\mathbf{J}$ and Allsop $\mathbf{J}$ as to whether wallets and purses are goods of the same kind as handbags in Colorado Group Ltd v Strandbags Group Pty Ltd, above n 139.

144 Thunderbird Products Corp v Thunderbird Marine Products Pty Ltd, above n 121, at 602; Re Yanx, above n 118.

145 Hall v Barrows (1863) 8 LT (NS) 227 at 229.

146 Hall v Barrows (1863) 4 De G J \& S 150 at 156 referring to Millington v Fox (1838) 40 ER 956.

147 See Settef SpA v Riv-Oland Marble Co (Vic) Pty Ltd, above n 129, citing Mouson \& Co v Boehm (1884) 26 Ch D 398.

148 Mouson \& Co v Boehm, above n 147. 
that the question of intention is one of fact, ${ }^{149}$ but abandonment should not be inferred from mere non-use of a mark. ${ }^{150}$

Relying on this case law, in Settef SpA v Riv-Oland Marble Co (Vic) Pty Ltd (Settef) McGarvie J expressed the view that "proprietary title to a trade mark is lost at common law by intentional abandonment but not by mere non use". ${ }^{151}$ In Settef it was found that an Italian manufacturer, Settef, had made use of the RIV-OLAND mark in Australia in 1967 and 1968. A distribution arrangement was terminated in 1970, but the Australian distributor continued to use the RIV-OLAND mark. Settef only obtained a registration in 1978 and upon learning of the distributor's continued use, it issued proceedings. The Australian distributor sought to invalidate the registration. Despite a significant interruption in Settef trying to export goods to Australia, delay in applying for registration, and the fact that Settef had "made little impression on the Australian market", McGarvie J found that Settef never formed an intention to abandon the RIV-OLAND trade mark. ${ }^{152}$ Settef's historical use was sufficient to support its claim to ownership.

Cases concerning common law marks that view property in an unregistered trade mark as being created by slight use could be regarded as "relics of a past time". ${ }^{153}$ Today, by virtue of the 2002 Act registered trade marks are recognised as property. ${ }^{154}$ Yet, absent a registration, the basis of judicial intervention in cases involving the misuse of trade marks is not based on property in a mark, but on property in goodwill. ${ }^{155}$ Whether a trader has sufficient goodwill to support a passing off claim is fact dependent. Nevertheless, it is tolerably clear that a trader must have some form of extant commercial reputation in the marketplace. As a matter of fact, goodwill may continue for a period when a business ceases to trade under a mark or it may fade away. ${ }^{156}$

Earlier case law concerning common law marks is inconsistent with the views in GE Trade Mark and in North Shore Toy that a common law property right in a trade mark can be lost through disuse. ${ }^{157}$ The better view may be that under the common law, a trader's "property rights" in an unregistered trade mark only exist for the "period in which the mark is distinctive of his goods in the

149 Mouson \& Co v Boehm, above n 147, at 404.

150 At $404-405$.

151 Settef SpA v Riv-Oland Marble Co (Vic) Pty Ltd, above n 129, at 426.

152 At 426. Upheld on appeal Riv-Oland Marble Co (Vic) Pty Ltd v Settef SpA (1988) 19 FCR 570 at 572 per Bowen CJ, and at 602 per Lockhart J.

153 New South Wales Dairy Corp v Murray-Goulburn Co-Op Co Ltd (1989) 86 ALR 549 at 568.

154 Trade Marks Act 2002, s 9.

155 Spalding $v$ Gamage, above n 16, at 284.

156 On this issue see generally Wadlow, above n 23, at [3.220].

157 GE Trade Mark, above n 11, at 326; North Shore Toy Co Ltd v Charles L Stevenson Ltd, above n 11, at 569. 
eyes of a substantial number of the relevant sections of the public". ${ }^{158}$ Where there is only slight use in the marketplace or where use has ceased for a sufficient period of time, such a standard would not be met.

\section{B Practical Problems}

In addition to doctrinal concerns, the low threshold of use and the lack of temporal limit create undesirable practical problems and strange situations. Rights in a registered trade mark can cease if a mark has not been put to genuine use for a continuous period of three years or more following registration. ${ }^{159}$ This requires an aggrieved person to file an application to have the unused trade mark registration revoked. Consider a situation where registered trade mark owner X commences use of its trade mark but thereafter ceases use and does not use its mark for a three year period. Trader $\mathrm{Y}$ files an application to register the same mark and soon thereafter files an application to remove X's mark to enable its mark to be registered and to avoid any infringement risk. Under the current law, even though X's mark may be removed from the register, $X$ could arguably successfully oppose Y's trade mark application for the same mark on the basis that it is the true owner of the trade mark because of its prior use. ${ }^{160}$

Burrell and Handler similarly posit a situation where trader A makes a small amount of use of a trade mark before ceasing use. ${ }^{161}$ Trader $\mathrm{B}$ then, in ignorance of $\mathrm{A}$, instead of seeking registration, commences use of the same mark and builds up a significant reputation in that mark. If B applied to register the trade mark at a later date, A could oppose the application claiming prior use. Likewise B may be able to prevent A from using its mark on the basis of passing off or the Fair Trading Act 1986. The result would be an impasse.

It could be argued that the doctrine of honest concurrent use could mitigate the undesirable consequences identified above. ${ }^{162}$ Section 26 of the 2002 Act provides that a mark may be registered if "a case of honest concurrent use exists" or "other special circumstances exist, that, in the opinion of the court or the Commissioner, makes it proper for the trade mark to be registered".

158 New South Wales Dairy Corp v Murray-Goulburn Co-Op Co Ltd, above n 153, at 568.

159 Trade Marks Act 2002, s 66(1)(a).

160 A point also made by Damien Broadley and Jude Antony "Tackling the Problem of Proprietorship" (2 April 2012) AJ Park Intellectual Property <www.ajpark.com>. It should be noted that the issue of discretion whether to remove a mark may come into play in such a situation, see the opposing views of Earl Gray and Karla Horstmans "Does a Residual Discretion Not to Revoke a Trade Mark for Non-Use Exist?" (2006) 4 NZIPJ 182 and Ian Finch and Amanda Holling "Discretion is the better part...?" [2003] NZLJ 217. In Manhaas Industries (2000) Ltd v Fresha Export Ltd [2012] NZHC 1815 at [35] Collins J appears to have confirmed that a discretion exists.

161 Robert Burrell and Michael Handler Australian Trade Mark Law (Oxford University Press, Victoria, 2010) at 243-244.

162 Burrell and Handler, above n 161, at 244. 
Section 26 has the marginal heading "Exceptions" and follows s 25 which prohibits the registration of trade mark applications that are identical or similar to registered trade marks. As a matter of statutory interpretation, honest concurrent use under s 26 arguably has no role to play when a prior use challenge is raised. This is because s 26 only appears to have work to do where a user of a trade mark in the marketplace is seeking registration of its trade mark in light of an existing registration not when registration is sought in light of an unregistered mark that has been used, or is being used in the marketplace. ${ }^{163}$

A more fruitful possibility would be arguing that s 26 allows registration (or continued) registration under the "other special circumstances" limb. This may give a court some wriggle room to accept that where there has been some concurrent use, or sustained use, in the marketplace prior to an applicant seeking registration, special circumstances exist that make it "proper for the trade mark to be registered". Yet, the fact that there is not an express honest concurrent use exception for this situation, and the necessity of relying on a vague "special circumstances" concept, again serves to illustrate the practical problems with prior use challenges under New Zealand law.

\section{Security and Incentives to Register}

The low standard of use in proprietorship cases also arguably risks diluting the certainty provided by the registered trade mark system. The purposes of the 2002 Act include clearly defining the scope of rights protected by registered trade marks and reducing business compliance costs generally. ${ }^{164}$ A registration system can be seen as meeting these purposes by providing valuable information about the ownership of marks in trade. ${ }^{165}$ For example, it enables those dealing with trade marks, such as licensees or mortgagees, to have confidence in the validity of title to a trade mark. From the perspective of those entering the market with a new product, a registration system is supposed to provide the advantage of enabling traders to inspect the Register to choose a mark to use that will not infringe the rights of others. ${ }^{166}$

For the Register to carry out its information role it needs to be accurate. ${ }^{167}$ Problems with the accuracy of the Register already arise with unregistered marks because of the system of dual protection explained above. However, where unregistered marks are only recognised when they are used in an open and notorious way, the accuracy problems are somewhat mitigated. In the age of

163 This is consistent with the view of Ronald Young $\mathrm{J}$ on the relationship of the honest use exception to $\mathrm{s}$ 17(1)(a). See Fonterra Brands (Tip Top Investments) Ltd v Tip Top Restaurant Ltd, above n 35, at [60]; Burrell and Handler, above n 161, at 244 and footnote 96.

164 Trade Marks Act 2002, s 3.

165 See also Burrell, above n 37, at 98.

166 At 98-99.

167 At 98. 
internet searching and marketing, traders have some comfort that an unregistered mark that is genuinely put to use in the marketplace is likely to be detected. The difficulty with the current law regarding prior use challenges is that marks that have been used only minimally or a long time ago are like submarines - difficult if not impossible to detect until they emerge. When they do, under the current law they have the potential to prevent registration of, or invalidate a registration for, a trade mark adopted and used in good faith.

The potentially latent character of prior use challenges also suggests an erosion of the security provided to a trade mark registration. From the perspective of a trader, a registration is intended to provide confidence for a trader to develop goodwill in a brand. A trader may wait until its mark is registered before committing resources to promotion of its brand and product on the basis that, once registered, it will have protection from misappropriation of its marketing efforts. Moreover, once registered, a trader may more easily negotiate the licensing of its trade mark as a licensee can have more confidence in the validity of the licensor's title. The ability of a mark to be challenged on the basis of prior use may dilute the stability of the grant of trade mark rights.

In addition, the ability of the owners of unregistered marks to oppose or invalidate marks on the basis of prior use may arguably reduce the incentive to register in the first place. ${ }^{168}$ From the perspective of a trader, it is normally easier to establish trade mark infringement than rely on passing off or a breach of the Fair Trading Act 1986. The attractiveness and the benefits of registration may be diluted if a trader is not guaranteed protection of their mark by virtue of a registration.

On its face, such concerns about security of grant and incentives to register may be alleviated by s 75 of the 2002 Act. Section 75 establishes a presumption that a trade mark registration will be deemed valid after seven years from the date of deemed registration, unless the registration offended against any of the absolute grounds set out in s 17. On a literal reading, a prior use challenge by way of s 32 would not interfere with this presumption of validity. However, as we have seen, IPONZ has been prepared to give prior users relief under the bad faith ground in s 17(2) or the contrary to law ground in $\mathrm{s} 17(1)(\mathrm{b}) .{ }^{169}$ The result of this interpretation is that a trade mark registration could be subject to an undesirable perpetual vulnerability to a prior use challenge.

The one saving grace is that in Chettleburgh, Woodhouse $\mathrm{J}$ expressed the tentative view that a discretion exists whether to invalidate a trade mark registration. Woodhouse J's view appeared to be supported by the fact that s 73 states that "the Commissioner or the court may ... declare a mark

168 Burrell and Handler "The Intersection Between Registered and Unregistered Trade Marks", above n 30, at 377

169 Finch, above n 84, at 463 asserts that "Although not specifically mentioned in s 17, it is also generally accepted that a false claim to ownership of a mark will also be treated as an absolute ground for refusing registration". 
invalid" as opposed to "the Commissioner or court must declare a mark invalid". In Chettleburgh Woodhouse $\mathbf{J}$ suggested that a discretion may be exercised where the "underlying merits" favour retention of the registration. ${ }^{170}$ In Chettleburgh Seduce Group relied on historical use of its mark between June 2001 and June 2003 that had ceased at the time Mr Chettleburgh applied for the same mark. Woodhouse $\mathrm{J}$ pointed out that these circumstances could raise questions of merit observing that there had been a short period of use, limited exposure of the goods in the marketplace and "a reasonably substantial period of no actual use of the mark at all". ${ }^{171}$

\section{The Continued Relevance of Prior Use Challenges?}

Given the doctrinal and practical issues identified above, it is certainly arguable that, just as rights to enforce unregistered common law marks have been removed in the 2002 Act, the law should bar the ability of traders to oppose proprietorship on the basis of prior use of unregistered trade marks. ${ }^{172}$ In my view, there would be significant merit in critically evaluating the continuing role of prior use challenges. Ideally, this should occur within a wider consideration of the interface between registered and unregistered trade marks generally. A more holistic examination of the role of prior use rights in the registered trade mark system may reveal no benefit or pressing need to retain prior use challenges based solely on prior use.

On the other hand, it could be argued that removing prior use challenges may result in some "unfair" outcomes. For example, in Chettleburgh, Seduce Group was able to establish prior use but was unable to establish an awareness in the relevant market of its mark at the relevant date necessary to succeed under s 17(1)(a). ${ }^{173}$ Further, as Mr Chettleburgh had filed the mark in ignorance of Seduce Group, there was no question of bad faith. Without a ground of objection based on prior use, Seduce Group would have been left without a remedy.

Reflecting on the result in Chettleburgh, it could be argued that retaining prior use challenges is beneficial as it rewards the person who best qualifies as the owner of the trade mark, rather than rewarding a person who simply wins the race to file. Relying on a natural rights theory of property, one could posit that the labour, skill and investment by a brand name creator should give it a property right in the brand name created. ${ }^{174}$ Further a brand creator should be protected from others "unfairly" misappropriating its investment. This kind of natural rights (or reap and sow) argument is intuitively appealing, but may be overplayed. The law tends to downplay the costs and efforts of

170 Chettleburgh, above n 95, at [62]. Support could also be drawn from Mouson \& Co v Boehm, above n 147, at 407-408.

171 Chettleburgh, above n 95, at [63].

172 See the comments of Baragwanath $\mathrm{J}$ in Red Bull v Meier, above n 62, at [48].

173 Chettleburgh [2011], above n 96, at [35].

174 See generally Belinda Isaac Brand Protection Matters (Sweet \& Maxwell, London, 2000) at 223-230. 
traders in creating a brand name. ${ }^{175}$ Nevertheless, without some public exposure via some form of use (or even the creation of awareness by advertising prior to goods being made available to the market), it is more difficult to justify that a person has made sufficient investment in the brand name to be deserving of protection or that a third party using the same brand name has "reaped where they have not sown". ${ }^{176}$ Chettleburgh would seem to be a rather unique case where there was use without the creation of any marketplace awareness. Closing the door to complainants in similar situations as Seduce Group could be seen as collateral damage in ensuring greater certainty to the ownership of registered trade marks.

It could also be argued that there should be some incentive for traders to help themselves by seeking registration, and failure to seek protection of a trade mark should not be indirectly rewarded. Valorising trade mark registration, though, does raise other issues. Despite some evidence suggesting that trade marks are frequently used by New Zealand businesses, and that firm size does not materially affect trade mark usage, ${ }^{177}$ there is a lack of empirical evidence concerning use of registered trade marks and use of the registered trade mark system by smaller enterprises. Anecdotal reports suggest that many small businesses may not seek registration of "their" trade marks. ${ }^{178}$ Instead, they may rely on passing off or the Fair Trading Act 1986 to protect against competitor misuse, or not give the matter much thought at all. The trade mark registration process may be perceived as costly by some small businesses, particularly if trade mark lawyers are engaged to advise on the process. It could be argued that removing prior use challenges may penalise small traders in comparison to larger players who are able to actively file and register multiple trade mark applications.

In response it is contended that removing a prior use ground of challenge will not necessarily adversely affect those small traders who, while not registering their marks, actively use them in the marketplace. For one, small traders are provided with a number of "shields" under the 2002 Act. As highlighted above, ${ }^{179}$ a prior continuous user of an unregistered mark has a defence to trade mark infringement. ${ }^{180}$ Moreover, a prior and continuous user may be able to rely on the honest concurrent use provisions of the 2002 Act to register its mark in light of an existing registration. ${ }^{181}$ Once a

175 For example results from a survey of 101 companies suggested that companies spend an average of 64 hours and USD \$7,600 in the brand naming process. See C Kohli and DW LeBahn "Observations: Creating Effective Brand Names: A Study of the Naming Process" (1997) 37 Journal of Advertising Research 67.

176 See Lionel Bently and Robert Burrell "The Requirement of Trade Mark Use" (2002) 13 AIPJ 181 at 185 186 on similar "reap/sow" arguments.

177 Sharp and Morgan, above n 36, at 69-70, table 22 and 84

178 For discussion of the Australian experience see Burrell, above n 37, at 101.

179 See footnote 34 and accompanying text above.

180 Although note the use would need to be "continuous", potentially excluding intermittent use.

181 See footnote 35 above. 
mark is registered, the 2002 Act provides a defence: a trade mark is not infringed by the use of another registered trade mark. ${ }^{182}$

In addition, small traders may also rely on certain "swords" in the 2002 Act, beyond proprietorship, to prevent duplicated use of their trade marks in the marketplace. Notwithstanding the unique circumstances in Chettleburgh, it should be reiterated that traders with prior rights are able to rely on other mechanisms to address most cases of deliberate or even innocent misuse or appropriation of marks. Section 17(1)(a), in particular, is arguably better able to balance the competing interests that are involved. Intervention on the basis of s 17(1)(a), at opposition or in an invalidation action, is premised on establishing some awareness in the marketplace of a mark that is then likely to lead to consumer confusion. Focusing on consumer confusion, rather than simply who used the mark first, may be preferable given trade mark law's classical motivation to protect consumers from confusion.

A focus on consumer confusion segues into the issue of whether removing a ground of challenge based on proprietorship may contribute to greater consumer confusion. Some law and economics scholars have sought to explain the function of trade marks, and the rationale of trade mark protection, in terms of the economic benefit of trade marks in reducing consumer search costs. ${ }^{183}$ According to this account, trade marks provide consumers with information about the quality and characteristics of goods and thereby reduce the costs involved in finding out such information directly. By protecting trade marks from confusing imitation, the informational value of trade marks to consumers is preserved. ${ }^{184}$ One could argue that, if prior use challenges were removed from the law, search costs may be increased, rather than decreased. Prior users would not be able to prevent subsequent adopters registering "their mark", even where that mark has fallen into disuse. Then consumers, when seeing a trade mark previously signifying one product now placed on a different product, could be confused or at least caused to feel some sense of wonder as to the nature and quality of the product. ${ }^{185}$

There are some notable New Zealand examples of brands that have fallen into disuse only to be reintroduced by their brand owners, including GEORGIE PIE, MELLO YELLO and CHOCOADES. ${ }^{186}$ It seems tolerably clear that, if a third party was to reintroduce these brands on different

182 Trade Marks Act 2002, s 93.

183 See generally William M Landes and Richard A Posner "The Economics of Trademark Law" (1988) 78 The Trademark Reporter 267.

184 See also Stacey Dogan and Mark Lemley "A Search-Costs Theory of Limiting Doctrines in Trademark Law" in Dinwoodie and Janis, above n 4, at 65.

185 A point made by Dogan and Lemley, above n 184, at 93.

186 See Veronica Schmidt "Sunday Insight: Nostalgia, Motherhood and Georgie Pie" The New Zealand Herald (online ed, New Zealand, 9 June 2013). 
products, search costs would be likely to increase. ${ }^{187}$ The increased search costs could even impose a deadweight loss because, instead of the trade mark signalling a product which the consumer was seeking, it could generate a product the consumer does not want to purchase and does not in fact purchase. ${ }^{188}$ In other words, there would be a net cost to society resulting from consumer not buying any products.

The situation, though, is different where there is no consumer recognition of a mark that has fallen into disuse. For consumers unaware of the mark and its earlier associated goodwill, the reintroduction of the mark will not mean anything. The prospect of increased search costs only arises where there is existing consumer recognition of the mark. Where this is the case, independently of a proprietorship ground of challenge, the original owners of such brand names would have a raft of legal remedies available, both outside the sphere of the 2002 Act and contained within it, to prevent third party use. For example, in the case of the mark GEORGIE PIE, sufficient goodwill is likely to have persisted in the marketplace and enabled the trade mark owner to prevent third parties adopting the mark based on passing off, even absent an extant trade mark registration. Consumers or any other interested party could also rely on the Fair Trading Act 1986 to take action to prevent consumer confusion in the marketplace. It is submitted that removing a test of proprietorship based on prior use, in and by itself, seems unlikely to sanction greater levels of consumer confusion.

A more compelling counterargument may be that the test of proprietorship based on prior use may help prevent parties rushing to stockpile trade marks they have not used or may not wish to use. The banking or stockpiling of trade marks is a well-recognised concern in the literature. ${ }^{189}$ The argument about stockpiling is certainly a relevant one, but it is addressed (or could be addressed) by trade mark law in other ways, such as strengthening the scrutiny placed on a trader's genuine intention to use prior to filing, raising the standard of use required to maintain a trade mark registration or removing some of the administrative burdens involved in revoking trade marks on the basis of non-use.

\section{RAISING THE THRESHOLD}

\section{A Greater Notice}

Even if a test of common law proprietorship is maintained - and Parliament's amendment to s 32 in 2005 can be construed as a clear indication that it will be - there is arguably merit in raising the threshold required to make good a claim of prior use. Thus, instead of the binary inquiry as to whether there is use or not, the law would be improved if the prior user had to establish

187 Dogan and Lemley, above n 184, at 93.

188 Michael Denniston "Residual Good Will in Unused Marks - The Case against Abandonment" (2000) 90 The Trademark Reporter 615 at 621.

189 See generally Batty and Watts, above n 51. See also Landes and Posner, above n 183, at 280. 
identification of its goods with the mark in the mind of the relevant market. ${ }^{190}$ In other words, it must be established that a substantial number of persons in the relevant market had an awareness, cognisance or knowledge of the mark so as to identify the goods bearing the trade mark with the adopter of the mark. ${ }^{191}$

The main benefit of a higher threshold is that it would be commensurate with the public being put on notice as to third party rights. A useful comparison can be drawn with United States (US) trade mark law. In the US only an "owner" can register a trade mark or enforce an unregistered trade mark. Priority of rights is determined by "use in commerce". ${ }^{192}$ A two-part test has been suggested to determine whether a trader has established prior use of a mark sufficient to establish ownership. ${ }^{193}$ Evidence must show adoption combined with "use in a way sufficiently public to identify or distinguish the marked goods in an appropriate segment of the public mind as those of the adopter of the mark". ${ }^{194}$ In an ownership context, to determine public identification some courts have suggested an assessment based on the "totality of the circumstances"195 or use that has some form of market penetration. ${ }^{196}$ In terms of assessing whether there has been use in commerce

190 It is noted that raising the standard of use would not mirror or make redundant the scope of s 17(1) as identity of marks and goods would still be a requirement to make good a challenge based on prior use.

191 This is an approach akin to that adopted under s 17(1)(a). See N V Sumatra Tobacco Trading Co v British American Tobacco (Brands) Inc, above n 55, at [77].

192 For federal registration purposes 15 USC $\$ 1127$ defines "use in commerce" as "the bona fide use of a mark in the ordinary course of trade, and not made merely to reserve a right in the mark". It has been asserted by some courts that the common law standard necessary to acquire rights in an unregistered trade mark is analogous to the statutory use in commerce standard, see Sodima v International Yogurt Co Inc 662 F Supp 839 at 853 (D Or 1987) and Planetary Motion Inc v Techspolosion Inc 261 F 3d 1188 (11th Cir 2001) at footnote 5. Compare Graeme B Dinwoodie and Mark D Janis Trademarks and Unfair Competition: Law and Policy (3rd ed, Aspen Publishers, New York) at 242 and Zazu Designs v L'Oreal SA 979 F 2d 499 at 503 (7th Cir 1992).

193 New England Duplicating Co v Mendes 190 F 2d 415 (1st Cir 1951) at 418 cited in Planetary Motion Inc v Techspolosion Inc, above n 192, at 1195.

194 New England Duplicating Co v Mendes 190 F 2d 415 (1st Cir 1951) at 417-418. The Court additionally pointed out that this could occur "even in the absence of sales". In the circumstances of the New England Duplicating Co v Mendes case the use relied upon to establish ownership was relatively minor as it only consisted of the publicising of the product in a leading trade periodical and the sale of two interleaving machines.

195 Planetary Motion Inc v Techspolosion Inc, above n 192, at 1195 referring to Johnny Blastoff Inc v LA Rams Football Co 188 F 3d 427 (7th Cir 1999) at 433.

196 Lucent Info Mgmt v Lucent Techns Inc 186 F 3d 311 (3d Cir 1999) at 317 referred to in Dinwoodie and Janis, above n 192, at 242-243. 
sufficient to found a registration, other cases have required evidence of use in commerce that is "open and notorious". 197

The use in commerce standard means that the chance of potential duplication of a trade mark is minimised. Discussing the use in commerce standard in the United States, Landes and Posner have suggested "a potential second comer will be on notice not to invest resources in developing a mark similar or identical to the one already in use". ${ }^{198}$ The current standard of use under New Zealand law arguably gives rise to situations where traders are not being put on notice of the existence of third party rights. This creates a greater prospect of inadvertent duplication when traders are seeking to clear a mark for use, creating inefficiency and wasted resources.

Again, there is an argument that a higher standard of use would unfairly penalise smaller traders. For example, because of a lack of funds or other initial hiccups, a start-up company may be slow to promote its trade mark or make sales of products bearing its trade mark subsequent to adopting it. ${ }^{199}$ The start-up company may therefore be deprived of the ability to challenge a second comer's application to register the same trade mark if the standard of use required it to establish some level of public identification associated with its trade mark. However, when it is realised that what is being advocated is an increase in the standard of use in order to increase notice to second comers, the argument of unfairness to small players loses some of its veracity. A prior user must at least establish that there is sufficient awareness of its mark to lead to the possibility that the public associates its trade mark with a product. ${ }^{200}$ The inquiry into public identification is highly fact specific and should be shaped by the practices of the particular industry or market. ${ }^{201}$ It is not necessary for sufficient public identification to be achieved by a high volume of sales of trademarked products. What is key is that the trade mark has come to the attention of the relevant market. Thus, in theory at least, a small trader is not necessarily confronted with an unlevel playing field.

Where a trader has made no or very little investment in promoting its adopted trade mark, the exposure of the trade mark to the marketplace will obviously be low or non-existent. The second

197 Aycock Engineering, Inc v Airflite Inc 560 F 3d 1350 (Fed Cir 2009) at 1361 referring to Intermed Communications Inc v Chaney 197 USPQ 501 at 507 (TTAB, 1997). Note also that the United States courts have adopted a doctrine of "analogous use" that allows activities that have a substantial impact on the public to establish priority, provided such activities are "tacked" to a subsequent actual use. See Dinwoodie and Janis, above n 192, at 255; and Amy Cohen "Intent to Use: A Failed Experiment?" (2001) 35 Univ San Francisco Law Rev 683 at 690.

198 Landes and Posner, above n 183, at 280.

199 See the dissenting judgment of Ackerman J in Lucent Info Mgmt v Lucent Techns Inc, above n 196, at 325.

200 Similar wording was used in Unilever PLC v McPherson's Consumer Products Pty Ltd [2013] NZHC 1458 at [16].

201 Planetary Motion Inc v Techspolosion Inc, above n 192. 
comer is consequently likely to be ignorant of the trader's adoption of the trade mark. As highlighted above, where there is no consumer awareness of the trade mark, there can be no confusion and resultant diversion of trade. This in turn makes it hard to see where the unfairness arises if a second comer were to coincidentally adopt the original trader's trade mark. If the original trader valued its adoption of its trade mark (independently of its use of it), it would have the option of applying to register its trade mark. The official costs of this process start at $\$ 172.50$ per class (including taxes). Registration would be "notice to all the world", ${ }^{202}$ and the act of registration would stake a trader's rights to the trade mark. Given the benefit of registration compared to the costs associated with any sort of promotion of a new brand name in the marketplace, the cost of registration does not seem unreasonable.

\section{B Search Costs and Abandonment}

A higher standard of use is also arguably justified taking into account the search-cost rationale for trade mark protection. Landes and Posner have argued if goods are not available in the marketplace the trade mark is not able to function as an information shortcut and confers no benefit. ${ }^{203}$ Drawing on this argument, a higher standard of prior use akin to public identification of the mark with its adopter may be preferred as it would be commensurate with reducing consumer search costs. Arguably, more than minimal use is needed to ensure a mark's signalling function can achieve a reduction in search costs. ${ }^{204}$

In addition, there would be benefit in requiring prior use of an unregistered trade mark to be continuous to support a prior use challenge. Under US law a trade mark is considered abandoned when use has been discontinued with no intent to resume use. There is a rebuttable presumption of abandonment after three years of consecutive non-use of a trade mark. ${ }^{205}$ It is contended that the operation of a similar presumption in relation to prior use challenges under New Zealand law would be desirable. It would make it more difficult for prior use challenges to succeed on the basis of limited historical and/or intermittent use of an unregistered mark in the marketplace. It would also create symmetry with the registered trade mark system, which allows marks to be revoked after three years of non-use. ${ }^{206}$

202 N V Sumatra Tobacco Trading Co v British American Tobacco (Brands) Inc, above n 55, at [80].

203 Landes and Posner, above n 183, at 280. See also Bently and Burrell, above n 176, at 186.

204 Mark Bartholomew "Making a Mark in the Internet Economy: A Trademark Analysis of Search Engine Advertising" (2005) 58 Oklahoma L Rev 179 at 204-205: "And even after a mark has been chosen, there must be a substantial commitment of resources to place that brand before the public so that the mark's signalling function can attract consumers and achieve the reduction in consumer search costs that is at the heart of trademark law."

20515 USC $\S 1127$.

206 I acknowledge and thank Earl Gray for this point. 


\section{CONCLUSION}

Under New Zealand's current law, a prior user of a trade mark is able to oppose an application to register a trade mark, or invalidate any existing trade mark registration, based on a common law test of proprietorship. This creates a number of unsatisfactory elements in the context of a modern registration system. The ability of a prior user to rely on historical or minimal use undermines the security provided by a registration, dilutes the incentives to register, and runs contrary to the purposes of the 2002 Act to increase certainty and reduce business costs. From a practical perspective, stalemate situations can arise where a prior user can prevent registration of a mark, but the prior user may itself be prevented from using the mark on the basis of passing off.

The unfavourable elements of the common law test of proprietorship suggest its retention is undesirable, or at least, that it needs to be modified. Indeed, in my view the 2002 Act would be able to address the large majority of conflicts as to ownership of trade marks by using mechanisms such as s 17(1)(a), which aim to prevent consumer confusion, or the bad faith ground of objection. Only a tiny proportion of cases would be affected if Parliament closed the door to challenges based on prior use. These rare cases would be collateral damage in ensuring greater certainty to ownership of registered trade marks. The likelihood of legislative change, though, is slight. Parliament has signalled that a proprietorship test based on prior use should continue to apply to the ownership of trade marks under the 2002 Act. In any event, there may be wisdom in forestalling any legislative change in favour of wider consideration of the interface between registered and unregistered trade marks generally. In particular, careful consideration needs to be given to how the opposition and invalidation mechanisms work and the role of the honest concurrent provisions in respect to unregistered marks with reputation in the marketplace. Such consideration is not academic. New Zealand's accession to the Madrid Protocol on 10 December 2012 - an international treaty that simplifies the procedure for persons seeking trade mark protection in multiple countries around the world - is likely to give rise to difficult issues with regard to unregistered rights.

To elaborate, international traders using the Madrid Protocol to extend trade mark protection to New Zealand may find their trade mark denied protection because of the rights of historical or localised prior users. From the perspective of local traders, using a New Zealand registration or application as the basis for extending trade mark protection to other countries, creates a risk of a prior use opposition or invalidation action "killing" the international registration. Under the Madrid Protocol, a New Zealand home application or registration that is cancelled within five years may result in an international registration being cancelled. ${ }^{207}$

207 The Protocol, above n 42, art 6(3) and 6(4) - this is known as a "central attack". See also Trade Marks (International Registration) Regulations 2012, reg 34(3). However, art 9quinquies of the Protocol allows the holder of the international registration that has been centrally attacked to transform an international registration into a national or regional application(s). 
If the test of proprietorship is maintained (which seems likely), the law could be improved by the judiciary and IPONZ adopting a stricter approach to the standard of use necessary to support a prior use claim. In particular, there may be merit in insisting that a challenger establish a higher threshold of use commensurate with the identification of goods with the trade mark in the mind of a substantial number of persons in the relevant market. Secondly, there would be a benefit in insisting that a challenger establish relatively continuous use, and in the absence of such continuous use a more ready inference that a mark has been abandoned. A higher standard would ensure third parties are put on notice of prior rights. It may also increase the level of reliability of the information contained on the Register as to the ownership of registered trade marks. 